\author{
Visión Electrónica \\ Más que un estado sólido \\ https://doi.org/10.14483/issn.2248-4728
}

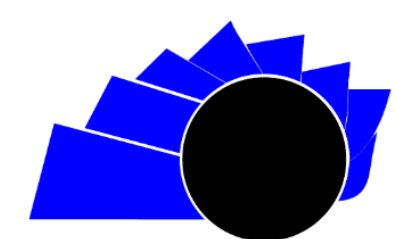

VISIÓN ELECTRÓNICA

\title{
Yuval Noah Harari, from Animals into Gods. A Brief History of Humankind. Bogotá: Penguin Random House, 2017, 492 pages.
}

\author{
Rosendo López-González iD ${ }_{1}$, Astrid Ramírez-Valencia (iD)
}

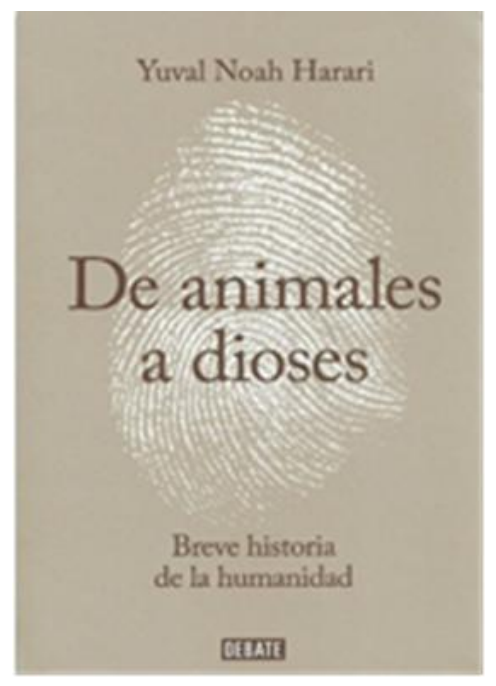

There is a well-marked objective in the book: to tell an ephemeral history of humanity, very similar to One Hundred Years of Solitude, but without the Buendía saga. The book is divided into four parts and an epilogue, namely: The cognitive revolution, The agricultural revolution, The unification of humanity, the scientific revolution. The epilogue, entitled The Animal that Became a God, ends with a distressing reflection on what the future of humanity could be: Is there anything more dangerous than unsatisfied and irresponsible gods who do not know what they want?.

In "From Animals into Gods" it is deliciously told how three revolutions affected humans; They are: the cognitive revolution about 70,000 years ago, the agricultural revolution about 12,000 years ago, and the scientific revolution only 500 years ago.

Now, the above -as in the whole story- is supported by archaeological and genetic studies. Harari, affirms that within the period covered, between 70,000 and 30,000 years ago, "the invention of boats, oil lamps, bows and arrows and needles" were made. Likewise, he asserts that "the first objects that can be described as" art and jewelry "also fit this period. In the same way, there is incontrovertible evidence of "religion, commerce and social stratification" [1, p.33-38]. This accumulation of knowledge, new and original, carried out by man "was the product of a revolution in his cognitive capacities." Baptizing it as a cognitive revolution without specifying what its causes were.

Consequently, the strong core of the most widely accepted theory of the cognitive revolution argues that this significant change is due to the fact that "accidental genetic mutations changed the internal connections of the sapiens' brains, allowing them to think unprecedentedly and communicate using a totally new type of language" $[1$, p.35]. Thus, the bulk of the cognitive revolution lies, for Harari, in the ability of Homo sapiens "to speak about fictions", pointing these out as the most unique characteristic. Add to this, that fiction has not only allowed us to imagine things, but to carry them out collectively. The professor of history at the Hebrew University of Jerusalem refers here to the possibility of ancient civilizations to hatch myths and stick together around them.

${ }_{1}$ BSc. In Chemical engineering, Universidad del Atlántico, Colombia. MSc. in Latin American Philosophy, Universidad Santo Tomás, Colombia. MSc. In Chemistry Teaching. Current position: Professor at Universidad Distrital Francisco José de Caldas, Colombia. E-mail: rlopezg@udistrital.edu.co

2 BSc. In Spanish-English, Universidad Distrital Francisco José de Caldas, Colombia. MSc. In Linguistics Applied to the Teaching of English, Universidad Distrital Francisco José de Caldas, Colombia. Ph.D. (c) In Language and Culture, Universidad Pedagógica y Tecnológica de Colombia, Tunja, Colombia. Current position: Member of the group GITEM++, Universidad Distrital Francisco José de Caldas, Colombia. E-mail: aramirezv@udistrital.edu.co

Cite this article as: R. López-González, A. Ramírez-Valencia, "Yuval Noah Harari, from Animals into Gods. A Brief History of Humankind. Bogotá: Penguin Random House, 2017, 492 pages", Visión Electrónica, vol. 14, no. 2, pp. 303-304, July 2020. https://doi.org/10.14483/22484728.16996 
The essence of the agricultural revolution consisted in transforming the way of feeding homo sapiens (hunter-gatherer): from a gatherer of wild plants and hunters of wild animals, homo sapiens spent almost all his time and effort manipulating the life of a few species of animals and plants. Harari states:

The transition to agriculture began around 9500-8500 B.C. in the mountainous country of southeastern Turkey, western Iran and the Levant. It started slowly, and in a restricted geographic area. Wheat and goats were domesticated around $9000 \mathrm{BC}$; peas and lentils around 8000 B.C. the olive trees around $5000 \mathrm{BC}$; the horses around 4000 B.C., and the vine in 3500 B.C. [1, p.95] 3 .

Add to the above, something surprising, since in other parts of the world agriculture also emerged but as an independent phenomenon. Thus, in Central America corn and beans were cultivated, the South Americans discovered how to grow potatoes and raise llamas; all this, unaware of what was being done in the Middle East.

So, according to Harari, what is the essence of the agricultural revolution? the exponential multiplication of Homo sapiens; the ability to keep more people in worse condition, he says. Or in other words: multiply the number of copies of the Homo sapiens genome.

The Scientific Revolution is the last part of the book; Harari begins with a beautiful dissertation called The Discovery of Ignorance. The story begins like this:

Imagine that a Spanish peasant had fallen asleep in $A D$ 1000. and he would have woken up 500 years later due to the din produced by the sailors of Colon when they came aboard the Nina, the Pinta and the Santa María. The world he would have woken up in would have seemed quite familiar to him $[1$, p. 275]4.

From where it follows that if the Spanish peasant wakes up in the 21st century, things are absolutely different. Starting with a question of population density, because in the year 1500 there were about 500 million homo-sapiens worldwide. Currently, there are 7 billion. Yuval marks as an important and transcendental milestone at this stage the birth of modern science, as well as the unwavering alliance between science, politics and the economy.

This leads us to an important difference between modern science and the other traditions of knowledge:

$\checkmark$ The disposition to admit ignorance and error in the construction of knowledge; thus, knowledge is a construct where the rationality of the individual intervenes, quite contrary to premodern traditions where everything important to know about the world was already known. The gods knew everything and revealed it to Homo sapiens through scripture or oral traditions.

$\checkmark$ Although it is true that modern science does not have dogmas; However, a new dogma that covers it is born, whose common core is empirical evidence. Coupled with mathematical tools.

$\checkmark$ Modern science is not satisfied with just creating new theories, since it uses these theories to acquire pompous powers based on the mastery of innovative technologies.

The book closes with an uncertain ending for Homo sapiens, and he envisions other beings to replace them, suggesting completely inorganic individuals in the manner suggested by Mary Shelley in 1818 in her book Frankenstein.

Thus, the new species would be super humans with genetic modifications in laboratories through intelligent design. Intelligent design is not produced by an Almighty but by a human, that is, man is the Supreme Being, hence the title of Harari's beautiful text. Ultimately, what is outlined in the last chapter is a reflection on the perpetuity of the human being.

This review comes to an end. In short, From Animals into Gods, it deals with an unlikely mutation that consists in transforming Homo sapiens into Homo Deus. I recommend the book. It is a beautiful story, very well written, very fluent and without saving words.

\section{References}

[1] Y. Noah Nahari, "From Animals into Gods: A Brief History of Humankind", Bogotá: Penguin Random House, 2017.

${ }^{3}$ Translated from the Spanish version "De animales a dioses: Breve ${ }^{4}$ Ibid historia de la Humanidad". 